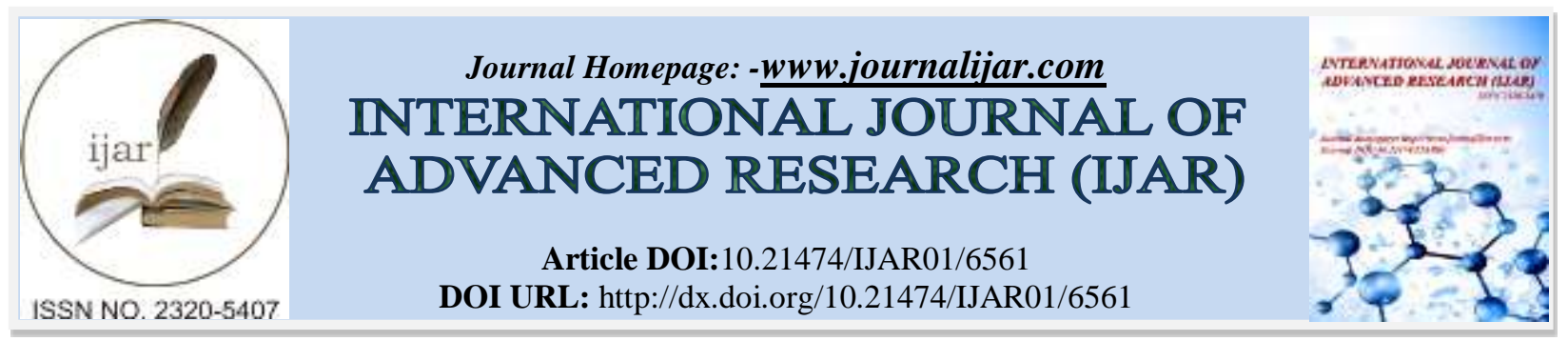

RESEARCH ARTICLE

\title{
A COMPARATIVE STUDY ON THE EFFECT OF ORGANIC FERTILIZER PANCHAGAVYA AND VERMICOMPOST ON THE YIELD OF ABELMOSCHUS ESCULENTUS (LADIESFINGER).
}

\author{
P.Vinnoli and S. Catherine P.Alexander. \\ Post graduate and Research Centre of Zoology, Jayaraj Annapackiam College for Women (Autonomous), \\ Periyakulam - 625601, India.
}

\section{Manuscript Info}

Manuscript History

Received: 17 December 2017

Final Accepted: 19 January 2018

Published: February 2018

Keywords:-

Ladies finger, Panchagavya, Vermicompost.

\begin{abstract}
The present study deals with the comparative analysis on the effect of organic fertilizers panchagavya and vermicompost on the growth yield of Abelmoschus esculentus (Ladiesfinger).The crop was divided into four plots. First plot was the control without treatment with panchagavya and vermicompost, Second plot was treated with panchagavya, Third plot was treated with vermicompost and Fourth plot was treated with panchagavya and vermicompost . It was observed that the treatment with panchagavya enhanced the various growth parameters like plant height, number of leaf, leaf length, number of flowers, flower length, number of fresh vegetables and weight of vegetables as compared to the plants which were grown on vermicompost and control alone.
\end{abstract}

Copy Right, IJAR, 2018,. All rights reserved.

\section{Introduction:-}

The greatest challenge facing by the nation in the coming years is to provide safe food for the growing population in the country. In this regard, organic farming which is a holistic production management system for promoting and enhancing health of agro-ecosystem, has gained wide recognition as a valid alternative to conventional food products and ensures safe food for human consumption. Excessive use of synthetic fertilizers and pesticides has caused tremendous harm to the environment as well as affects human population indirectly. The use of synthetic chemical fertilizers lead to imperfectly synthesized protein in leaves, which is responsible for poor crops and in turn for pathological conditions in humans and animals fed with such deficient food (Talukdar et al., 2003).

Farmers are well aware with the use of organic liquid manures such as Panchagavya, Beejamrutha, Jeevamrutha and Biodigester in organic farming. These organic liquid manures play a key role in promoting growth and providing immunity to plant system.

In Sanskrit, Panchagavya means a combination of five products obtained from cow. When suitably mixed and used, these have miraculous effects. Panchagavya is used in different forms such as foliar spray, soil application along with irrigation water, seed or seedling treatment etc. (Natarajan, 2002).

Vermicompost converts organic wastes to useful fertilizers and modify the physical, chemical and biological properties of soil, promoting growth of the above ground vegetation. Plant growth is modified mainly by changing soil physical structure, mineralization processes, hormone-like effects, dispersal of plant growth stimulating 
microorganisms antagonistic to root pathogens (Lavelle et al., 1998). The vermicomposting contains high nutrient value as fertility of soil and maintains soil health. (Suthar et al.,2005).

\section{Materials and methods:-}

The present study deals with the comparative analysis on the effect of organic fertilizer panchagavya and vermicompost on the yield of vegetable crop ladies finger.

\section{Preparation of panchagavya:-}

Panchagavya consists of five products from the cow dung, urine, milk, curd and ghee. When suitably mixed and used, these have miraculous effects (Mudiganti Ram Krishna Rao et al., 2015). Fresh Cow Dung (5 Kg), Cow Ghee (1 Litres), Cow Urine (3 Litres), Cow Milk (2 Litres), Cow Curd (2 Litres), Sugar Cane Juice (3 Litres), Water (2 Litres), Banana (15) were used as ingredients for panchagavya preparation.

The fresh cow dung, cow urine, water and ghee were mixed thoroughly and kept in a plastic container and was covered with clean piece of cloth and kept in shade for three days. The mixture was stirred twice in a day and allowed to ferment for 15 days. On the 18th day, rest of the ingredients (Banana, Cow milk, Sugar cane juice, Cow curd) were added in the mixture and allowed to ferment for further seven days while stirring twice a day. On the $25^{\text {th }}$ day Panchagavya was ready to use. The mixture was filtered with a thick cloth and the clear solution was stored in an air tight vessel and was stirred every morning and evening till use. Cow urine was added in case the solution become thick. The products of only native breed of cows were used. When stirred twice daily, the Panchagavya solution can be kept for six months without any deterioration in its quality. Whenever the solution becomes thick due to evaporation of water was added to keep it in a liquid state.

\section{Preparation of vermicompost:-}

The digestion of organic wastes into compost by using earthworms is called vermicomposting. Vermicompost was prepared by following method of Rakesh Joshi and Adarsh Pal, 2002.

The organic wastes $(15 \mathrm{~kg})$ such as leaves, plant trimmings, kitchen wastes, paper bits, egg shells. Etc., is spread, on an open land, to about $5 \mathrm{cms}$ height. Cowdung $(10 \mathrm{~kg}$ ) is then piled to a height of $8 \mathrm{cms}$. Earthworm (Eudrilus eugeniae) was collected from vermicompost preparation place at Cumbum in Theni District. About 100 earthworms (Eudrilus eugeniae) are introduced into this cowdung to effect composting. Enough water is sprinkled on the cowdung uniformly. Wet organic wastes are piled on the cowdung to a height of 2 feet and water regularly.To prevent evaporartion, the pile may be covered with coconut leaves. The wastes become vermicompost within 45 days.

After 45 days, compost is allowed to dry. When moisture level comes down in the compost, earthworms go to the worm bed and reside there. Then compost is excavated from the pile without damaging the worm-bed.

\section{Experimental set up:-}

Soil from the garden was mixed with different concentrations of Panchagavya and vermicompost was used in the experiment. Four treatments were prepared as follows:

I plot was the control

II plot (Soil + Panchagavya): The Organic Liquid Fertilizer is in a concentrated form. $30 \mathrm{ml}$ of this liquid is mixed with one litre of water to make 3\% solution. This solution is sprayed / sprinkled and also applied to the roots to get the desired results. Once in 7 days, it is sprayed to the all crops.

III plot ( Soil + vermicompost): 20 gms of vermicompost per plant and also applied to the roots to get the desired results.

IV plot (Soil + Panchagavya and vermicompost): The above dose of vermicompost and Panchagavya in continuous is applied to the plants.

Four plots of size $120 \mathrm{~cm} \times 90 \mathrm{~cm}$ were used to determine the growth of ladies finger seeds in each of the four treatments. A total of 5 ladies finger seeds with spacing of $3 \mathrm{~cm}$ were sown at a depth of $3 \mathrm{~cm}$ in each plot. Hence, a total of 20 seeds were sown in four plots of each treatment. Growth was determined in each of the four treatments after 9 days. Growth parameters were recorded using scale. Growth was measured once in an every week in terms of plant height, number of leaf, leaf length, number of flowers, flowers length, number of fresh vegetables, weight of vegetables. Harvesting was done after 40 days. In yield per week Vermicompost and Panchagavya was compared. 


\section{Statistical Analysis:-}

Statistical analysis of the data obtained was done using the following formula:

$$
\begin{gathered}
\text { Arithmetic mean } \dot{\mathrm{X}}=\sum \mathrm{x} / \mathrm{N} \\
\dot{\mathrm{X}}=\text { Total } \\
\sum \mathrm{x}=\text { Sum of all observation } \\
\mathrm{N}=\text { Number of observation } \\
\text { Standard deviation }(\mathrm{SD})=\sqrt{\sum(\mathrm{x}-\dot{\mathrm{X}}) / N-1}
\end{gathered}
$$

\section{Observation and Results:-}

In this study a comparative analysis on the effect of organic fertilizer panchagavya and vermicompost on the yield of vegetable crop ladies finger was carried out. The height of the plant, number of leaves per plant, leaf length, and number of flower per plant, flowers length, number of vegetables and weight of vegetables were measured once in a week. The results are depicted in figure 1-7.

Figure 1 depicts the effect of organic manure in ladies finger in terms of leaves per plant. On certain weeks (IV week), panchagavya treated plants exhibited more number of leaves per plants. On other weeks the panchagavya and vermicompost treated groups showed more number of leaves than the other groups. Comparing all the four groups' panchagavya and vermicompost treated group exhibited more number of leaves.

Figure 2 depicts the size of leaf length per plant. On certain weeks (IV, VII) panchagavya, (V, VIII). On other weeks (I, II, III, VII) the panchagavya and vermicompost treated groups showed more leaf length than the other groups. Comparing all the four groups' panchagavya and vermicompost treated group exhibited more leaf length per plant.

Figure 3 depicts the effect of organic manure in ladies finger in terms of number of flowers per plant. On certain weeks (V, VI) panchagavya, (III, V) vermicompost, (IV, VIII) panchagavya and vermicompost treated plants exhibited more number of flowers per plant.

Figure 4 depicts the size of flower length per plant. On certain weeks (VI week) panchagavya, (III, VI) vermicompost, (IV, VIII) panchagavya and vermicompost treated plants exhibited more flower length per plant.

Figure 5 depicts the effect of organic manure in ladies finger in terms number of vegetables per plant. On certain weeks ( VI,VII week) panchagavya, (IV) vermicompost, (V,VIII) panchagavya and vermicompost treated groups showed more number of vegetables per plants.

Figure 6 depicts the weight of vegetables per plant. On certain weeks (VI, VII) panchagavya, (IV) vermicompost, (V, VIII) the panchagavya and vermicompost treated plants exhibited more weight of vegetables per plant.

Figure 7 depicts the effect of organic manure in ladies finger in terms of height of plant per plant. On all weeks the panchagavya and vermicompost treated groups showed more height of plant than other groups . Comparing all the four groups' panchagavya and vermicompost treated group exhibited more height of plant.

From the above results it can be concluded that the plants treated both with panchagavya and vermicompost in combination the groups produced better results than treated separately with panchagavya and vermicompost. 
Fig 1:- Effect of panchagavya and vermicompost on the no. of leaves of ladies finger.

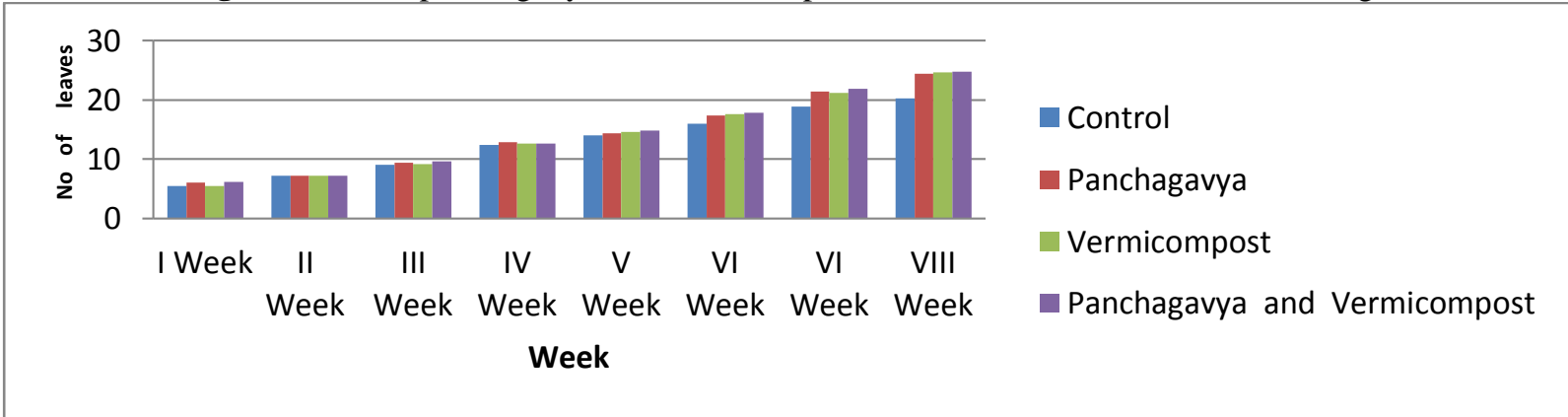

Fig2:- Effect of panchagavya and vermicompost on the leaf length of ladies finger.

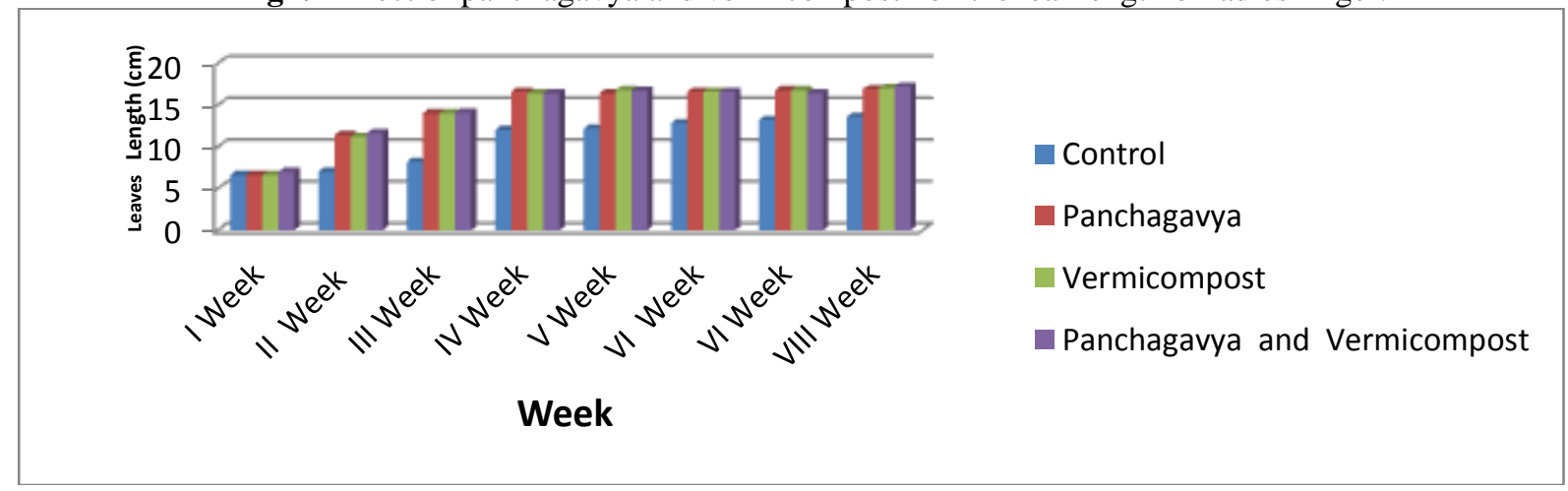

Fig 3:- Effect of panchagavya and vermicompost on the no. of flowers of ladies finger.

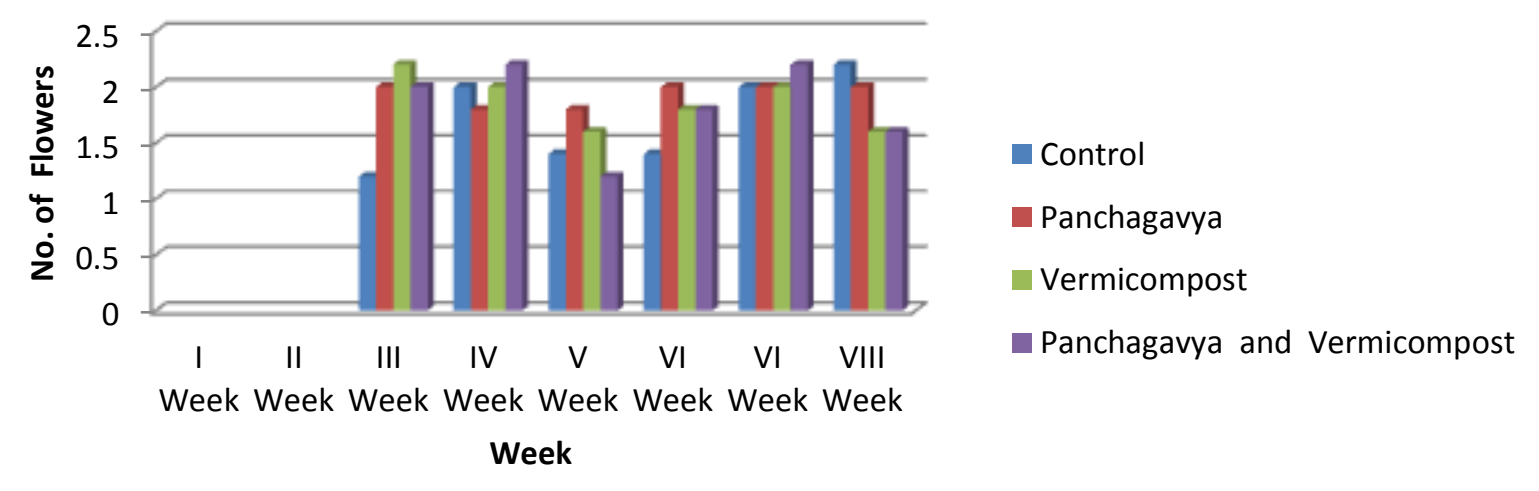

Fig 4:- Effect of panchagavya and vermicompost on the flowers length of ladies finger.

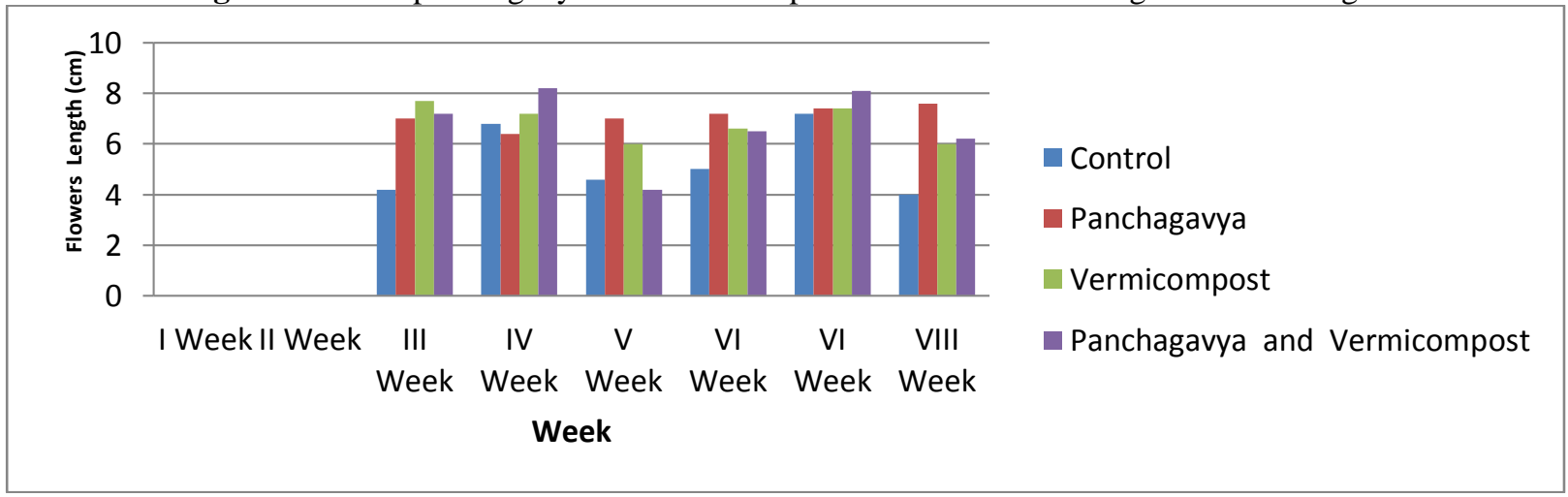


Fig 5:- Effect of panchagavya and vermicompost on the no. of vegetables of ladies finger.

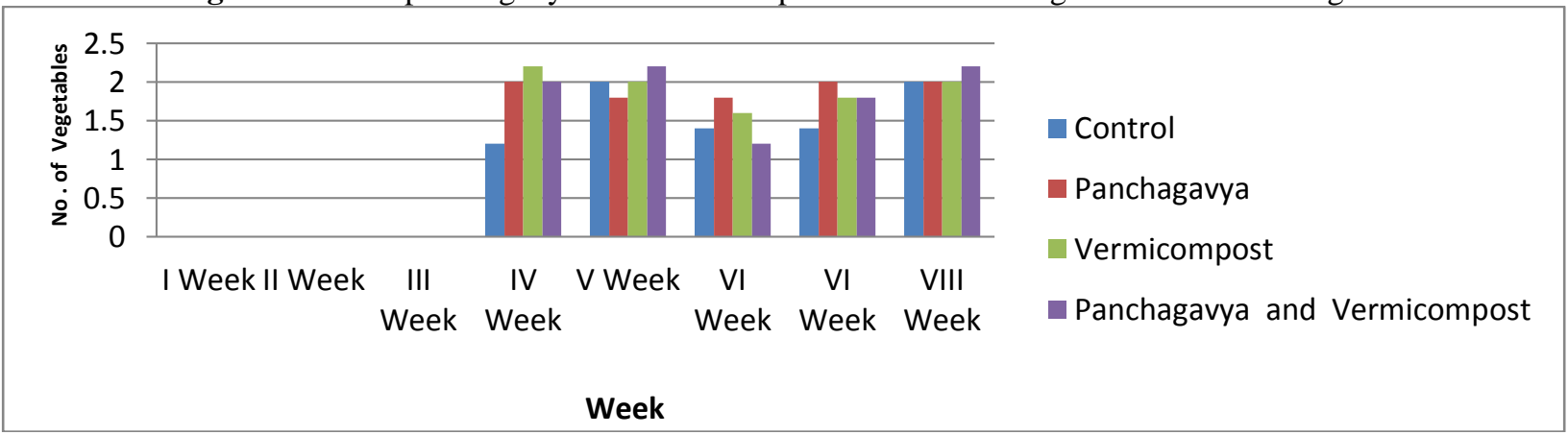

Fig 6:- Effect of panchagavya and vermicompost on the weight of vegetables ladies finger.

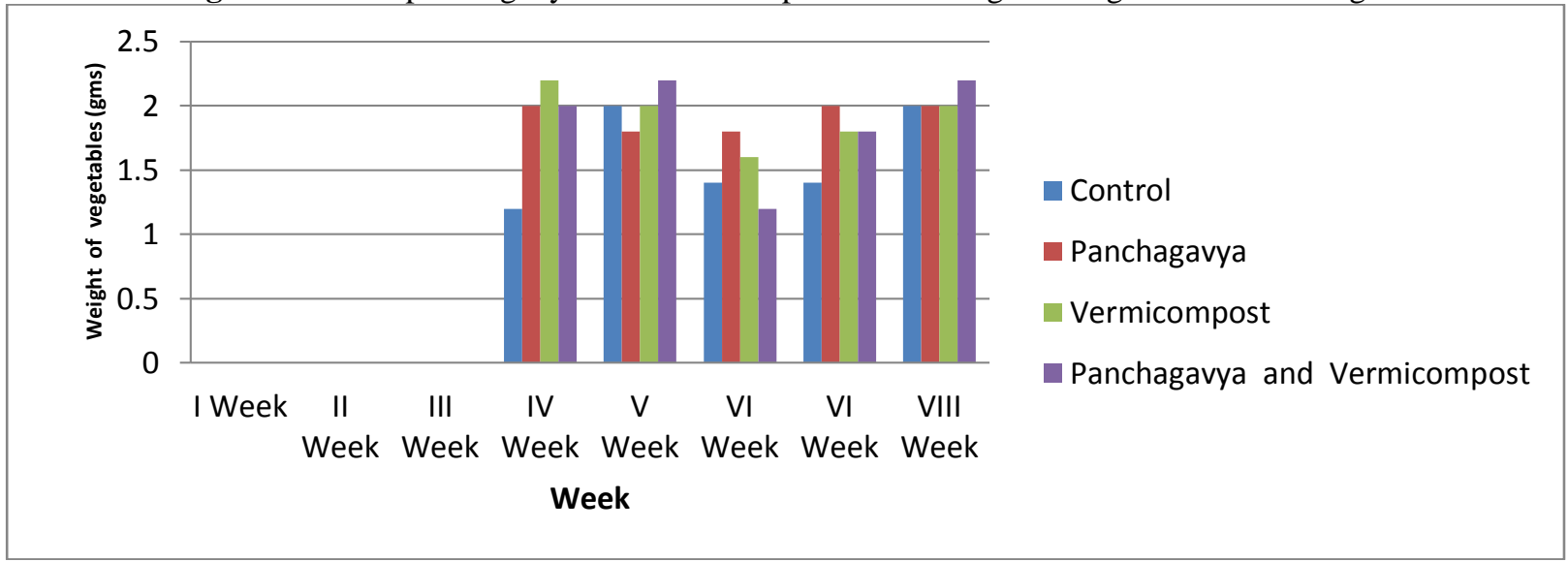

Fig 7:- Effect of Panchagavya and Vermicompost on the Plant height of Ladies Finger.

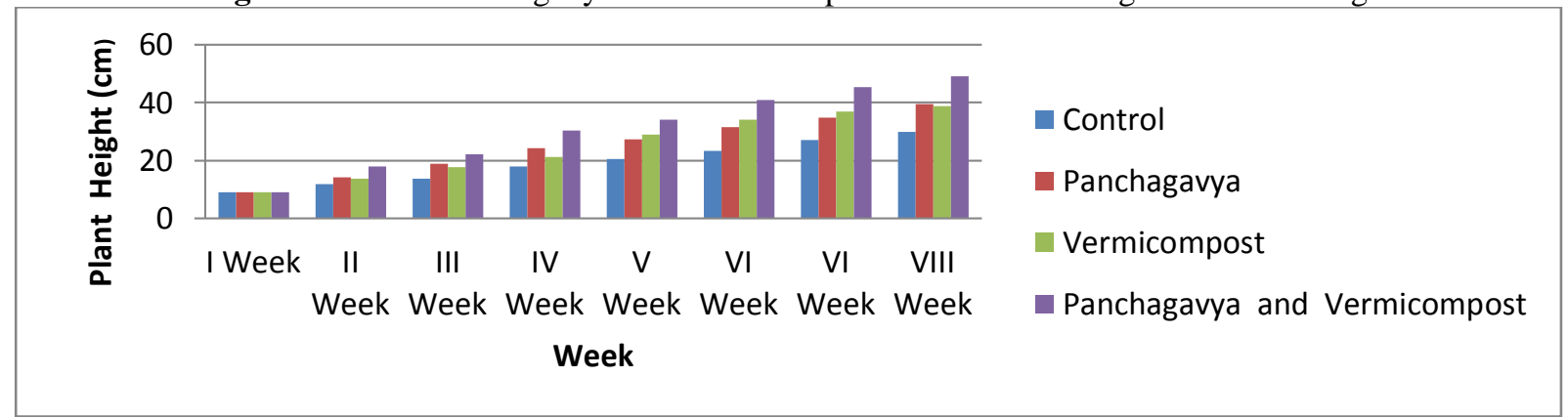

\section{Discussion:-}

In the present study, growth parameters were significantly higher with the application of Panchagavya and vermicompost. From the above study it is very clear that the use of vermicompost and panchagavya have produced better results as compared to other groups in ladies finger.

According to Muthuvel (2002) four sprays of panchagavya and Moringa leaf extract spray @ $25 \mathrm{ml} /$ plant resulted in higher plant height, number of branches per plant. Panchagavya @ 3\% resulted in a significance increase in the yield attributes. Swaminathan et al ., (2007) concluded that application of Panchagavya at 3\% as foliar spray on 15, 25, and 40 days after sowing (DAS) on black gram recorded the highest grain yield of $1195 \mathrm{~kg}$ ha .

Vennila (2008) revealed that application of 100 per cent recommended dose of fertilizer along with panchagavya spray (2\%) significantly increased the number of fruits per plant, fruit weight $\mathrm{g}$ fruit ${ }^{-1}$ and fruit yield $\mathrm{q} \mathrm{ha}^{-1}$ of okra. 
Ali et al., (2011) studied the effect of panchagavya and sarifibani, liquid organic manure on the yield of green gram, Vigna radiata, chilli, Capsicum frutescens (Chili) and mustard, Brassic campestris

Our strategy aims at using organic manure to get better results, stopping the use of chemicals as fertilizers and pesticides, thus giving a richer, healthier and economically feasible alternative traditional farming. It is concluded that with the use of vermicompost and panchagavya, the yield of ladies finger crop was considerably enhanced.

\section{References:-}

1. Ali, M.N., Ghatak, S. and Ragul, T. (2011). Biochemicalanalysis of panchagavya and sanjibani and thei effect in crop yield and soil health. Journal of Crop and Weed, 7(2): 84-86.

2. Lavelle, P. (1988). Earthworm activities and soil system. Biol. Fertial. Soil. 6: 237-251.

3. Mudiganti Ram Krishna Rao, M. Sathish Kumar, B. and Neema Kumari Jha, N. (2015). Comparative yield analysis of Chilli (Capsicum annuum L.) by application of Vermicompost and Panchagavya Department of Industrial Biotechnology, Bharath University, Chennai.

4. Muthuvel, N. (2002). Effect of organics on growth and yield of bhendi var. varsh uphar. Proc.nation. conf. on glory of gomatha : Panchagavya as potentiator of plant cells: Effects on crop plants and the physiology that validates the effects, Dec. 1-3, 2007, S. V. Veterinary Univ., Tirupati, A.P., pp.143-148.

5. Natarajan, K. (2002). Panchagavya - A Manual. Other India Press, Mapusa, Goa, India. In India, pp: 333. On yield attributes and economics of rice (Oryza sativa). Crop Res., 31: 1-5.

6. Rakesh Joshi, G. and Adarsh Pal, V. (2009). Effect of Vermicompost on Growth, Yield and 39

7. Quality of Tomato (Lycopersicum esculentum L) Department of Botanical and Environmental Sciences, Guru Nanak Dev University, Amritsar-143005, Punjab, India

8. Suthar, S.S., Watts, J., Sandhu, M., Rana, s., Kanwal, A., Gupta, D., Meena, M.S. (2005). Vermicomposting of kitchen waste by using Eisenia Foetida (SAVIGNY). Asian Journals of Microbiology, Biotechnology, and Environmental science 7, 541-544.

9. Talukdar, N., Thakuria, D. and Goswami,C. (2003). Organic Farming and Quality of Organic Food. Journal of chemical and pharmaceutical sciences, pp: $150-151$

10. Vennila, C. and Jayanthi, C. (2008). Response of Okrato integrated nutrient management. J. Soils Crops, 18:3640. 